\title{
Food irradiation legislation due despite public suspicion
}

\section{London}

THE British government is expected soon to legalize the irradiation of food as a means of sterilization, bringing Britain into line with 29 other countries, including most of its partners in the European Economic Community (EEC). Treatment of food with ionizing radiation is at present prohibited in Britain, as it is in West Germany. All the other EEC states allow the process for certain specified foods.

Last year, the independent Advisory Committee on Irradiated and Novel Foods (ACINF) presented the British health minister with a report on safety aspects of food irradiation. Its overall conclusion was that there was no evidence to justify the continuing ban on food irradiation, provided that specified dose limits were not exceeded.

Shortly after parliament resumes in October, the government is likely to

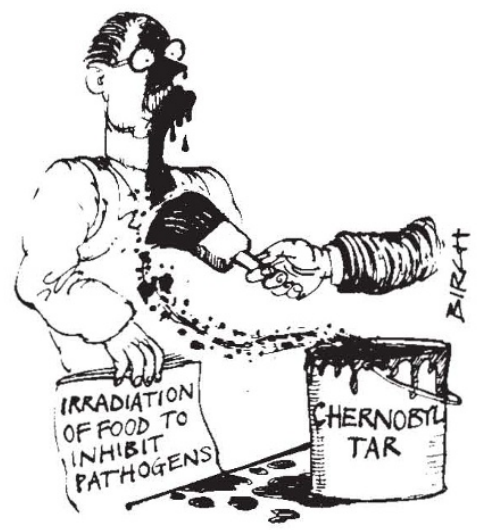

announce legislation to permit the irradiation of certain foods, the three most likely candidates being spices, grain and poultry. The European Commission is also considering the subject, in the context of its 'internal market' policy, which is intended to make possible the free movement of foodstuffs between member countries by 1992

The Commission is preparing a draft directive on irradiated foods. If, as seems probable, the directive is adopted and if Britain and West Germany have not by then legislated, they would be obliged to follow the directive unless, within 18 months, they could provide evidence of toxicity arising from irradiation.

The ACINF report recommends an overall average dose limit of 10 kilograys, sufficient to delay ripening or kill pathogenic microorganisms without rendering the food radioactive.

Opponents of the method point to potential difficulties in the enforcement of controls. There is at present no reliable means of identifying the small quantities of novel radiolytic products formed within irradiated food, making it almost impossible to determine efficiently if a food has or has not been irradiated, or how many times. In the absence of such tests, controls would need to be enforced by strict documentation at irradiation plants, a method, say the opponents, fraught with the potential for abuse.

Other commonly expressed fears are that the process could cause the selective survival of pathogens, formation of bacterial or fungi toxins, or the creation of resistant or harmful mutants. Despite ACINF's assurances that 30 years' investigation has produced no evidence of such effects, in the wake of Chernobyl a suspicious British public is bound to ensure that legislation will be given a rough passage.

Simon Hadlington

\section{Extra mileage in ethanol for Chirac Paris}

France continues to support plans to convert part of its grain and beet mountain to ethanol, a petrol substitute, despite rejection of the idea by its partners in the European Economic Community (EEC). Although all the evidence shows that the scheme would be uneconomic, Prime Minister Jacques Chirac is anxious not to offend powerful agricultural lobby groups before the 1988 presidential elections.

At present the export of surplus grain to the developing countries is subsidized by the EEC. Farmers have argued that this subsidy could directly be converted to an ethanol production subsidy.

But a study commissioned by the European parliament shows that ethanol costs four times as much to produce as petrols, or other fuel additives. A much larger subsidy than that required to export the surplus grain would be needed to turn the grain into alcohol. Without help from its European partners, such a scheme would cost the French government FF3,000 million a year.

But there may even be some political mileage to be gained from going against the rest of the EEC and supporting the scheme in France. A 1983 law allows French petrol to contain up to 5 per cent ethanol. Over the past two months, Chirac has reduced the tax on ethanol and encouraged its use. That pleases the agricultural lobby and, by a remarkable sleight of hand, it costs the government nothing.

Because of its low calorific value, adding ethanol reduces fuel efficiency and as much comes back from value added tax on the extra petrol sold as is given out in concessions.

Peter Coles
Britons beating CERN drum

\section{London}

BRITISH employees at the European highenergy physics laboratory (CERN) at Geneva are taking early action to influence the British government's decision, expected later in the year, on its continued membership of the 12-member organization.

In a statement put out earlier this week, Eifionydd Jones, chairman of what he called the CERN-UK Working Group, says that British scientists working at CERN, of whom there are 334, believe that the British government's decision on whether or not to continue as a member is imminent, and that "there is a very real threat" that Britain may withdraw from membership.

A large part of the accompanying case for continued membership is the argument that developments in high-energy physics have stimulated the development of accelerators for treating cancer patients (of which there are now more than 1,000 world-wide), similar facilities for the production of short-lived radioactive isotopes and machines for carrying out ionimplantation of the kind used in the manufacture of microcircuits.

The CERN-UK working party claims the turnover of Oxford Instruments Ltd. (quoted as $£ 55$ million a year), a successful manufacturer of superconducting magnets, as one of the benefits of highenergy physics to the outside world. These examples are cited as proof that basic research and technology develop hand-inhand.

The working-group's "FACT PACK" also includes what is in effect an appeal to British manufacturers to take competitions for CERN contracts more seriously. While CERN goes to considerable lengths to arrange that competition for tenders will be equitable, basing its awards on factory-gate and not delivered prices, British companies have not usually recovered what they might consider to be their fair share of CERN's capital spending.

An important part of the working party's recommendations is that those who receive its information-pack should "speak out to all those with influence and a voice in public affairs". The group's statement says that the idea of the United Kingdom's withdrawal from CERN "seems incomprehensible to our European colleagues".

How correct may be the working party's estimate of when the British government will decide about continued membership is not clear. The most likely timing of that event is just before the next council meeting of CERN, fixed for December. 